\title{
The semiotics of violence Ninja, sorcerers, and state terror in post-Soeharto Indonesia
}

In July 1998, two months after President Soeharto resigned from power, several reports appeared in Indonesian and international media of a series of killings taking place in Java. The killings initially involved the murders of people suspected of practising black magic (dukun santet). Many of the alleged sorcerers and victims were kyai, venerated scholar/teachers of Islam who head boarding schools (pesantren). The bloodshed, entailing the killing of several hundred people over a period of five months, from July to November 1998, has come to be known as the 'ninja killings', named after the fabled Japanese martial arts experts with supernatural powers. The reason for this name is that the perpetrators of the killings, rumour had it, were dressed in black-clad ninja fashion and possessed mystical powers similar to their Japanese counterparts.

While the first phase of the killings was marked by stories of ninja perpetrating violence, events in late October took a new turn. Media reports and rumours circulating in markets and neighbourhood gatherings now portrayed ninja as the victims of violence; numerous individuals suspected of being ninja assassins were dying at the hands of angry 'mobs', beaten to death and, in some cases, decapitated at numerous locales across East and Central Java (see also Van Dijk 2001:362-9; Kroeger 2003:253).

Violence, fear, and rumours reigned over the island at that time, as the state apparatus proved to be incapable of identifying, arresting, and trying the masked assassins. Justice was increasingly dispensed by kampung (neighbourhood) residents who, having reactivated or instantly set up night watches, took the situation into their own hands. The authorities' ineffective response also prompted a number of independent organizations, whose political role was becoming increasingly important in late- and postSoeharto Indonesia, to carry out their own investigations of the incidents. Their findings reiterated what was said in roadside food stalls and small

KONSTANTINOS RETSIKAS is Lecturer in the Anthropology of Southeast Asia at the School of Oriental and African Studies, University of London. He completed his PhD on ethnicity and personhood in East Java at the University of Edinburgh. He can be reached at the Department of Anthropology, SOAS, University of London, Thornhaugh Street, Russell Square, London, WC1H 0XG, United Kingdom. E-mail: kr1@soas.ac.uk. 
prayer houses among kampung residents, who dissociated the ninja killing spree from the practice of sorcery and the world of sorcerers, macabre and threatening as it was. In its place, they firmly drew up new associations, accusing shadowy figures in the Indonesian military and the New Order bureaucracy of launching a campaign of terror.

In what follows, I examine the socio-cultural basis of this dissociation and the reasons behind my interlocutors' alignment of terror with the New Order state, its machinery of surveillance and security apparatus. In particular, I explore the significance of this claim - what it says about the relationship between the state and local people's ideas about justice, power and leadership, and their evolving historical trajectory in the current context of Indonesia's emerging democracy. While producing compelling narratives about power and legitimacy that communicated their grievances and anger towards the New Order, local-level interpretations rested crucially on revisiting a period from the past which was previously little talked about. That earlier period is similarly characterized by the occurrence of unnatural death, rumours, and communal massacres. The violence of that period involved not black-clad assassins praying on alleged sorcerers, but the physical elimination of the Communist Party, an event that heralded the birth of the New Order and shaped Indonesian politics for years to come.

During the first months after Soeharto's fall, history made a second appearance, embracing everybody in its tight embrace. Making sense of the ninja killings, identifying culprits, and locating motives, required recourse to the past and necessitated alternative formulations of the anti-communist purge in which many in the locality had participated - some as victims, others as aggressors; some having been more active, others less so. The road to establishing a more just and democratic form of polity, the key vision that spawned the reformasi movement and culminated in Soeharto's resigation on that fateful day in May 1998, was mediated by acts of remembering. Memories of a violent past made an unexpected and compelling reappearance, opening up avenues for the cognitive containment of ninja, showing the way towards their expulsion from the body politic. In this scheme, the reconfiguration of the past, as Zurbuchen's recent edited volume (2005) makes aptly clear, is a deeply political act directed principally to present dictates and future desires. Under the political conditions prevailing in the immediate months after Soeharto's resignation, the ninja killings were made sense of by the application of an interpretative politics that made use of the past so as to understand and influence the political contours of the present and the future.

My analysis here of the meanings and consequences of the appearance of ninja both elaborates on and diverges from insights of other recent studies, and offers new perspectives on the understanding of the place of violence 
and rumour in Java. Without disputing the possibility that the backbone of the ninja 'operation' might have been formed by army deserters of Komando Pasukan Khusus (Kopassus, Special Forces Command), a claim that Cribb (2000) has put forward, noting the strong parallels between the Petrus killings of the mid-1980s and the ninja ones, I choose to adopt an approach that seeks to unravel these killings from the perspective of the effects produced by the narratives about the ninja assassins. Instead of simply asking 'What happened' and 'Why?', I ask 'What is it that the ninja tell us about Java in the aftermath of Soeharto's resignation?', 'How were these specific interpretations arrived at?', 'By whom?', and 'What is it that makes these interpretations credible and truthful?' (see Purdey 2004:191). In an important article, Thufail (2005:166), writing on the same events, notes that local responses to the ninja killings 'mediate anxieties about political transformation' and, more particularly, about the form and content of the Indonesian nation and nationalism in the post-New Order era. Questions of anxieties also inform Siegel's superb account (2001) of the witch-hunts that took place in East Java, a year or so after the events my article is primarily concerned about. For Siegel, the witch-hunts were primarily the result of the failure of the state to maintain the structures of recognition and surveillance that regulated as much the relations between the state and its citizens, as relations among the citizens themselves. In such a situation, the culture of fear the New Order had fostered through the images of the communist and the criminal were given a new twist, and a new source of menace was identified as residing within the local setting: the witch. Violence against the witch was thus an attempt to reassert social control. Such a resort was, in Siegel's analysis (2001:68), quite reactionary in the sense that it was part of the legacy of the New Order, while its revolutionary potential, though present, was of limited import. The argument I put forward, though greatly inspired by and broadly compatible with Siegel's overall approach, points the other way round and shows that the renegotiation of the past on which ninja narratives rested was, if not quite of revolutionary proportions, then at least of a certain discontinuity with the discursive practices of the New Order.

Issues of uncertainty and anxiety are centre stage in yet another article that deals with the ninja killings. Campbell and Connor's study (2000) makes the case that the ninja killings and the ensuing killings of suspected ninja by 'mobs' (massa) cannot be adequately accounted for by explanations, whether academic or 'indigenous', that see them as politically motivated. To this end, they provide evidence that sporadic killings continued well into the year 2000 , after the political situation in the country had changed with the election of a new president. Citing the work of the Comaroffs (1993) on Africa, among others, they assert, but do not persuasively demonstrate, that the 'attacks can be understood as an expression of the tensions and contradictions of 
globalization and social transformation in East Java that are not confined to the period of acute crisis in late 1998, but are an ongoing expression of deep ideological divides, state repression, and social inequalities' (Campbell and Connor 2000:88). While I do not wish here to discount the role played by the economy and global market forces, especially since Indonesia was (and still is) undergoing an acute economic crisis, two things are worth noting. First, the social transformations and inequalities that the authors refer to, though undeniably part of the overall context, do not seem to have a direct and unequivocal bearing on the killings since clear class distinctions did not at any point differentiate perpetrators from victims (see also Siegel 2001). I will return to this issue in the conclusion, when discussing the Comaroffs' work. Second, and most important, this approach relies on an expressive model of violence according to which violence communicates what is otherwise linguistically inexpressible. It thus occupies the status of a metaphor, if we were to define the latter in narrow terms, that we as analysts can attempt to decipher but they, our subjects, cannot. The approach I adopt in my analysis is different. Violence is constitutive rather than expressive of social relations. In other words, we cannot presuppose the existence of an already constituted field of social relations about which violence makes statements. Rather, violence is a form of sociality and a means for defining and structuring social relations, whether we find this ethically reprehensible or not.

Violence, remembered and forgotten, physical as well as spectral, narrated, rumoured, and enacted, is, as Jonathan Spencer (1992:262) has argued, 'a particular kind of socially meaningful action'. This is a crucial observation, for it reflects changing directions within anthropological studies. Rather than bifurcating the treatment of violence into the legitimate use of force by the state and the brutality of vigilante mobs, or construing it as emanating from pre-social, irrational, or even primordial urges and loyalties, in need of being contained and disciplined, commentators now stress what Steedly (1999:445) calls 'the full particularity of its multifarious occasions', examining the contexts of its production, deployment, and representation; the ways it is instigated, disciplined, and imagined by both perpetrators and victims (Das 1990; Riches 1986; Sluka 2000; Smith 2001). Violence in this sense is historically constituted (Schulte Nordholt 2002), and its practice and discourses have the capacity to produce meanings, formulate identities on the basis of a process of Othering, as well as define relationships in the context of state power both in the colonial and postcolonial eras (Goldstein 2003; Taussig 1984, 1987; Comaroff and Comaroff 1999; Gordillo 2002). However, as Spencer (1992:267) reminds us, rarely does violence makes itself felt in the form of first-hand experiences of destruction and death. Rather, it has the ability to create its own space of intersubjectivity circumscribed by the effects of rumours. Rumours of violent death that announce images of phantasmic enemies, that 
is of surreal but not fabricated versions of menace, often constitute both the source and the loci of violence as narrative and mediate violence as action. Ghosh (1998), who has looked into the turbulent Hindu-Muslim relations in South Asia, stresses the role of rumour in the production and reproduction of violence, noting that the way this is accomplished relies on rumour's appeal to cultural themes and values. In a similar vein, Drake (1989) argues that rumours of construction sacrifice in Borneo, Indonesia, achieved credibility precisely because of being situated within a particular cultural logic and historical relations with powerful state agents. In this respect, rumour can be seen not simply as a derivation from the truth, but, as Kapferer (1990) notes, as the seeking out of truth by a concerted effort.

In the present article, I am not occupied with the Sisyphean task of documenting cases of ninja violence and ascertaining whether the rumours of black-clad assassins roaming the countryside were true or false. I have no 'evidence' for proving or disproving their existence and deeds. Moreover, the locality in which I undertook my research from October 1998 to March 2000, the semi-urban settlement of Alas Niser (pseudonym) situated in the periphery of the municipality of Probolinggo and populated by Madurese and Javanese speakers, ${ }^{1}$ was not the site of such killings. As such, I have no ethnographic or other 'first-hand' accounts to offer. Despite this wholly welcome absence of physical violence from my fieldwork area, the ninja were a constant source of fascination and fear, awe and suspicion for my interlocutors. In this instance, moving beyond questions about the veracity of events and doing justice to my interlocutors' intense interest in ninja stories necessitates a focus on narrative and rumour as the source of the experience of terror, in a manner similar to that outlined by Taussig $(1984,1987)$. The terror narratives in question are events as reported in the press and disseminated by word of mouth, turned into rumours and hearsay, modern fables of uncertain times. Press reports and rumours - that is, mediated knowledge about ninja - constitute an assemblage of ambiguous images of carefully crafted detail and offer an extraordinary capacity for mapping the political. Let me now turn to these issues.

1 Alas Niser's current inhabitants identify themselves as 'mixed people' (orang campuran), that is as neither Madurese nor Javanese but rather as wholly distinct due to spatial intermingling and intermarriage. The majority of Madurese speakers are descendants of migrants from the island of Madura, principally the provinces of Pamekasan and Sampang, who arrived in the area during the mid-nineteenth and early twentieth century in a massive rural exodus. Apart from a small minority of Javanese speakers who are native to the area, the majority of Javanese speakers are either migrants themselves or descendants of migrants who originate from a multitude of villages and towns in Central Java and western East Java. Their arrival in Alas Niser is closely associated with state sector employment and the expansion of state services in the post-independence period. See Husson (1995) on Madurese migration to East Java and Retsikas (2003) on migration to Alas Niser and the practices that have allowed for the emergence of 'mixed people'. 


\section{Naming a national menace}

In addition to classic Southeast Asian images of lurking danger encapsulated in the figures of the head-hunter (Ellen 2002; George 1996; Hoskins 1996; Rosaldo 1980; Tsintjilonis 2000), and the witch or the sorcerer (Howe 19992000; Watson and Ellen 1993; Wikan 1990), a new iconography of menace has recently arisen. This iconography has come to be used for a multiplicity of figures. The figures involved are associated with increasing state penetration in remote areas, missionary activity, and the process of globalization brought about by multinationals, foreign workers, tourists, and manufactured commodities. Ethnographers working in the Indonesian archipelago have documented this trend towards an overcrowding of disruptive forces. For example, rumour panics in Borneo and Flores, involving fears that local children are abducted and sacrificed in order to strengthen the foundations of new buildings, have been directed against missionaries and civil servants (Drake 1989; Erb 1991; Tsing 1993). Foreign tourists in Sumba are suspected of collecting the blood of local children to coat their electronic devices, so as to increase their longevity (Hoskins 2002). Similarly, in Java, stories of shoppers being stuck with AIDS-infected needles by unknown assailants have spread panic among middle-class consumers (Kroeger 2003).

The ninja are a relatively new addition to this list. Genealogically speaking, they made their first appearance in East Timor during the early 1990s. Aditjondro (2000) and Kammen (2001) mention rumours of black-clad masked assassins making nightly forays during the era of military operations in the then occupied territory, raiding the houses of suspected pro-Independence sympathizers, beating or killing them on the spot. ${ }^{2}$ Ninja squads first made themselves known in Java in October 1996, during the anti-Christian and anti-Chinese riots in the town of Situbondo on the northern coast of East Java. ${ }^{3}$ A couple of years later, in January 1998, the town of Banyuwangi, also in East Java, was the site of rumours of alleged sorcerers being knifed or bludgeoned by unidentified black-clad assassins. That month, in the district of Banyuwangi, about ten people accused of sorcery were killed by what the

2 Both authors claim that the ninja squads in East Timor had received military training and were working for the military. They also link them with Major General Prabowo Subianto, Soeharto's son-in-law.

3 Hefner 2000:190-3. Hefner too claims that the ninja role in the Situbondo affair was politically engineered. Ninja are described by Hefner as provocateurs who intended to inflict damage on Nahdlatul Ulama and its leader, who was working on improving relations between the Muslim and the Christian communities in Indonesia. According to the same author, the reappearance of ninja in 1998 and the killings of alleged sorcerers in Banyuwangi was a 'clear attempt to pit NU Muslims against abangan Javanists' and to worsen the ties between the political parties such communities are usually associated with (Hefner 2000:210). 
police later identified as local hoodlums (Brown 2000; Campbell and Connor 2000). Despite their prosecution, no official account appeared as to why they had carried out the attacks or whom they were working for. The issue remained largely unresolved, only to re-emerge two months after Soeharto's fall from power.

The Banyuwangi murders occurred while Indonesia was experiencing its worst economic crisis since the inception of the New Order. The crisis, sparked by currency problems in Thailand in July 1997, soon spread over East and Southeast Asia, causing a rapid loss of investor confidence and capital flight to other destinations. In Indonesia, it marked a sudden downturn in the economic fortunes of the country. Over the next year, the rupiah lost much of its value against the US dollar, causing businesses to default on debt payments, which in turn exposed critical weaknesses in the banking sector. The end result was many factories ceasing operations and laying off staff, while prices of both basic goods and imported items rocketed sky high. The severity of the situation was marked by the poor of Indonesia growing to an estimated 40 per cent of the total population in late 1998, and the economy contracting by about 10 per cent over the same year. In contrast to other parts of Southeast Asia, in Indonesia the economic crisis also triggered a political crisis. Demands for economic reform were accompanied by increasing calls for political reform, as one of the basic supports of Soeharto's legitimacy was eroded. Amid extraordinary scenes of student protests, anti-Chinese riots, and looting in Jakarta in May 1998, Soeharto stepped down. His successor, B.J. Habibie, promised elections during the following year.

Two months into what was a major victory for the reformasi movement and amid jubilation about Soeharto's resignation, the national and international press reported that ninja had re-emerged in Banyuwangi. Reports and rumours spoke of killings carried out by assassins who would appear in the middle of the night from nowhere, storm an alleged sorcerer's house, slash his throat in seconds, and then disappear into the dark (see, for example, Jawa Pos 1998a, 1998b, 1998c). The new wave of menace quickly spread throughout rural East Java as similar cases were reported from the districts of Jember, Situbondo, Bandowoso, Pasuruan and Sampang, and Pamekasan. By autumn, the killing spree entered Central Java (Jakarta Post 1998a, 1998b). The national newspaper Surya (1998) claimed that, by July 1998, the total number of victims was around 50, while by October the number had risen to 150. Among the victims of ninja violence were many kyai, venerated scholars of Islam who head Islamic boarding schools. According to the former head of Nahdlatul Ulama's East Java chapter, Hasyim Muzadi, a total of 14 kyai had been killed during July, while by late October the number of kyai murdered was claimed to be over half of the total killed (Surya 1998). The murdered kyai were all said to be members of Nahdlatul Ulama, Indonesia's largest 
Islamic organization. As for the rest of the victims, they were only identified as suspected dukun santet, that is, people who were said to possess sorcery knowledge/power (ilmu) and had a variety of occupations.

In late October 1998, events took a new turn. Rumours began spreading that the ninja were feigning insanity so as to be passed off as nonthreatening and to be able to travel long distances without having to produce identification papers (Tapol 1998; Singapore Straits Times 1998b; see also Thufail 2005). Shortly after, news broke of 'mobs' (massa) attacking, beating, and killing mentally disturbed strangers both in East and Central Java (Kompas 1998a). The Jakarta Post (1998a) reported that in the district of Pemalang in Central Java, a barefooted and raggedly clothed stranger was killed by a local 'mob' when he failed to show his identification papers and tried to run away. Locals who took him for a ninja chased him and beat him to death. In the district of Malang in East Java that same month, locals who were on the lookout for ninja confronted another mentally ill person, who had wandered to a rural village several miles away from his home. When the man produced no identification, he was attacked by men armed with sickles and machetes, who chopped off his head, and then paraded it impaled on a knife with his body dragged behind a motorcycle (Moreau 1998; Kristof 1998; see also Van Dijk 2001:365). Other stories made the situation even more confusing and alarming. A few cases of ninja accusations were attributed both by newspapers and the police to the settlement of old scores between neighbours. In the district of Temanggung in Central Java, the killing of a villager was said to be a case of revenge, under the veil of ninja accusations (Jakarta Post 1998a).

The police and the army were reported in the press as making arrests after each murder of either suspected dukun santet or ninja. However, most of the suspects were freed shortly afterwards due to insufficient evidence. Occasionally the police killed individuals (Singapore Straits Times 1998a) while trying to place them under arrest. For the most part, however, police officers were urging the rakyat, the 'people', not to take the law into their own hands. Wiranto, then commander general of the Indonesian armed forces, was quoted as saying that 'people should not be influenced and provoked by any forms of terror. We must improve our national unity' (Indonesian Observer 1998b). The then deputy national police chief took a somewhat different stand. He was quoted as saying that people took the law into their own hands because they believed the police would not punish either the sorcerers or the ninja assassins. He went on to disclaim such a conviction by maintaining that the police had already arrested 125 people suspected of involvement in the killings (Indonesian Observer 1998b). The deputy's comments reflected some of the things going on in the minds of both the general public and members of reformasi organizations working to eliminate the armed forces' political role in Indonesia. 
The Surabaya chapter of the Lembaga Bantuan Hukum (Legal Aid Foundation), a nongovernmental organization, carried out an independent investigation into the killing spree while questions about the identity of perpetrators were still officially unanswered. The investigation, also supported by the Commission on Missing Persons and Victims of Violence, claimed that there were strong indications that the mass killings were organized and perpetrated by paramilitary groups with the intention of creating mass insecurity in Java (Indonesian Observer 1998c). The aim was to capitalize on this insecurity so that 'the people' would be obliged to seek protection from the armed forces. In this way, the report continued, the armed forces' political role would be deemed necessary for the common good and the reformasi movement would suffer a major blow in its attempt to democratize the Indonesian polity (see also SiaR News Service 1998a, 1998b; Kompas 1998b). This conclusion was reported to have been reached on the grounds that several arrested perpetrators appeared to have had military training.

The results of the investigation were made public a few days after Abdurrahman Wahid, then head of Nahdlatul Ulama, stated that he knew the identity of the masterminds and implied that they were all top government officials (Indonesian Observer 1998a, 1998d; see also Priyono et al. 1998). Nahdlatul Ulama carried out its own investigation into the matter and their results made the same point (see Lajnah Kajian dan Pengembangan Sumberdaya Manusia Nahdlatul Ulama or LAKPESDAM-NU, Nahdladul Ulama Institute for the Study and Development of Human Resources 1999). The Nahdlatul Ulama report, though taking a broader view of killings and sorcery in East Java that was not simply confined to the murders of kyai, stated that the ninja killings had been organized five months in advance by government and military members. The report named the then regent of Banyuwangi as the crucial link between top government and military officials and the assassins, on the grounds of a list of names identifying 500 individuals as sorcerers. The regent was said to have publicized all 500 names on a radio broadcast back in February 1998. According to the report, the aim of the murders was to spread chaos, pitting Indonesians against each other, and launching a campaign of terror that was to prevent people from supporting Partai Kebangkitan Bangsa (PKB, National Awakening Party), which at that time its members construed as the political arm of Nahdlatul Ulama. ${ }^{4}$

4 Nahdlatul Ulama was founded in 1926 as a religious, educational and social welfare organization dedicated to promoting traditionalist understandings of the Islamic faith against the resurgence of Islamic modernism. From 1952 to 1983, however, it functioned as a political party. In 1983, under the repressive policies of the New Order, it withdrew from overt politics and focused its activities on membership consolidation, the propagation of the faith, and the pursuit of political ends by means of heightening the Islamic consciousness of the country's people. Hefner (2000:87) refers to Nahdlatul Ulama's ideology as a 'potent mix of nationalism, Javanese 
As with every interpretation, Nahdlatul Ulama's views were informed by particular political positions and interests, most notably its indirect re-entry into party politics. As such, its take on events is highly biased. As a result, a number of issues in the report remain unresolved. For example, as Campbell and Connor (2000) rightly point out, in several of the cases investigated, there is no evidence of the presence of outside instigators or provocateurs. Moreover, several of the attacks against Nahdlatul Ulama members, the report recognized, were carried out not by ninja but by locals, fellow villagers, some of whom were supporters of the very same organization. As Siegel (2001:76) notes in his appraisal of Nahdlatul Ulama's position, its accusation of the military was credible because the army was clearly to blame for a number of instances of violence perpetrated in the past. Moreover, it afforded Nahdlatul Ulama the possibility to avoid casting suspicion and doubt on its own supporters. Had Nahdlatul Ulama not put all the blame on the army, it would have had to get to grips with the very uncomfortable situation of certain cases where both killers and victims were among its own members and supporters. However, such was the anti-New Order and anti-military climate during the period following Soeharto's resignation that such inconsistencies were not broadly questioned, and the associated positionalities remained largely uncontested. ${ }^{5}$

\section{Ninja through discourse}

The limited ability or general unwillingness of the state apparatus to identify, arrest, and try the assassins, as well as to publicize the findings of its investigations and the trial proceedings, when these took place, further eroded the authority of the New Order state. Embattled by the economic crisis and political accusations of korupsi, kolusi and nepotisme, the state did not offer the appropriate recognition of the incidents, or give protection, for that matter. The lack of effective response allowed the rumours and news to follow a trajectory beyond state control. Making sense and 'truth' out

ethnic pride and multi-interest pragmatism' and, of course, Islam. The organization is centred upon the world of kyai and their Koranic boarding schools, which are also the main recruiting grounds for its members and future leaders. It has vast followings in both Central and East Java, mostly among the peasantry.

5 Some military officers did try to control the direction of rumours and accusations, and in this respect, they put the blame for the ninja killings on survivors of the anti-communist massacres of 1965-1966 and their relatives (see also Van Dijk 2001:366). The assumption was that communists were now trying to avenge these past killings through a new round of retributive violence targeting Nahdlatul Ulama members. Nahdlatul Ulama and its youth wing had played a major role in the 1965-1966 massacres. 
of rumours became, for the most part, the property of those contesting the state's legitimacy.

Nahdlatul Ulama's investigation reiterated and confirmed the way many locals of Alas Niser conceived of the killings. As did both reports, locals dissociated the presence and acts of ninja from the practice of mystical arts. Instead, they accused elements within the New Order of dabbling in violence in order to stage a comeback. Locals' way of knowing emphasized an interpretative capacity based on the recognition of signs, a practical semiotics of political life. In establishing this dissociation, my interlocutors' identification of ninja and the real causes of the killings were based on a series of signs. Such signs were interpreted against a backdrop of public knowledge about black magic, the usual responses to it, spirits, setan, the army, television images, the events as reported in the media, and the timing of the reports. They also resorted to past experiences, either lived or narrated, in order to explain present events and to safeguard their community and relations from the violence that was pervading the island of Java.

Alas Niser remained largely untouched by the ninja assassins. The near absence of disruption made locals feel proud of the situation in their locality compared to other places in Java. However, they were well informed about the killing spree through reading newspapers and hearing TV news broadcasts. Furthermore, despite never having encountered a ninja, my interlocutors questioned neither that the killings took place nor the existence of blackclad assassins. On the contrary, they were quick to offer detailed descriptions of this new menace.

Ninja were construed as dressed in black clothes and wearing a black hood, carrying either keris, the traditional wavy double-bladed dagger, or samurai swords, sleeping in the daytime and acting during the night. They were also said to be martial arts experts and to possess ilmu, supernatural knowledge or power. Such ilmu enabled them to be in two different places at the same time. It also allowed them to reduce their bodyweight to the lightness of a feather so as to climb trees in a single bound. Ninja were also conceived of as able to fly or disappear upon coming in contact with water in rivers or ponds. In addition, they were assumed to act in groups of four to six. Although most ninja were said to be men, there were also some female ones. They would approach the house of the victim deep in the night when most people were asleep. Then, two of them would enter the house and cut the victim's throat while the rest kept guard in trees. They would all disappear immediately after the murder, or flee when a villager, becoming aware of their presence, started screaming.

Certain characteristics signalled the potential malevolence of ninja. Among these, a key feature was their black clothing. People refer to sorcery by a variety of terms, and the term ilmu hitam (black knowledge/power) is used 
interchangeably with ilmu santet, ilmu sihir and kemudhung (Madurese). Jenang hitam (black porridge), one of the five ritual offerings in life-cycle and agricultural ritual meals, represents nafsu aluamah, the greediness and cruelty inherent in human beings, which a pious person must learn to bring under control. Accordingly, impious and evil persons are said to be led astray from Allah's path because they cannot 'see' Him due to their hearts/livers becoming black (hati hitam). The potential evil nature of ninja was reinforced by their association with nighttime, a time when black magic is performed, thefts commonly occur, ghosts wander near cemeteries terrifying innocent passers-by, setan torment the faithful in their dreams, and jinn penetrate human bodies, afflicting them with illness and death (see also Howe 1999-2000).

Ninja were construed to be spirit-like, and their spirit nature partook of the occult and its ambiguities. Their similarity to spirits is seen in their association with trees and water, normally taken as the dwelling places of spirits, and the claim made by some that one could see ninja only if one had fasted for three consecutive days. Fasting is regarded as one of the most common means to acquire a spirit familiar. Such a spirit helper can be either malevolent or benevolent, a 'friend of Allah' or a sworn enemy of His commandments. Fasting and meditation are commonly practised so as to bring humans into contact with the supernatural world. This is achieved through the 'opening' of one's batin (inner self) to a realm which cannot be perceived through any of the five senses. The moral make-up of this realm encompasses both good and evil, and thus the opening of one's self can entail encounters with beings of either category.

The ambiguity surrounding ninja ontology - were they spirits or humans? - also cropped up in relation to questions about their origins. Ninja were thought to be either Javanese, for they used the traditional Javanese dragonshaped keris, or Japanese, for they carried swords emblematic of the warrior class of feudal Japan. Indonesians are quite familiar with other Asian cultures' warriors and martial arts experts through Asian movies, shown at cinemas and on television. In contrast to other post-colonial states like India, which have experienced a surge in cinematic production, Indonesia has come to rely increasingly on imports from the US and Asia to cater for its millions of television viewers. During the last ten years, Indonesian production companies have entered the market, and several domestic series are now broadcast. In these productions, martial arts expertise is accompanied by the possession of one or another kind of ilmu by the hero, who makes use of ilmu to defeat powerful evil opponents. When I asked my co-viewers whether such people really existed, they claimed either that they did exist in Java but only in the past, for present-day Indonesians do not have the necessary inner strength (kuat batin) to possess such ilmu, or that they still existed in places far away from Java and that's why they have never seen any of them, except 
in movies. Could it be, then, that ninja 'jumped out' of screens and acquired an independent existence?

Dracula makes a case for this. James Siegel (1986), in his book Solo in the New Order, talks at great length about the popularity enjoyed by a ketoprak play carrying the title 'Mrs. Dracula from abroad' in the city of Surakarta, the first of a series of plays with Dracula as their focus. The play was performed on Thursday nights, the time spirits are believed to be out, and such was its success that it was reported in the Surakarta press that Dracula, the 'real' spirit, was sighted in Java, Bali and Madura. She was also reported to have attacked a Japanese construction worker in a hotel, who had to be rushed to the hospital (Siegel 1986:91, 321). Dracula and, according to one version, ninja too are of foreign origin and owe their very existence in the local repertoire of recognized beings because they were introduced by means of modern media, whether theatre, television, or cinema. ${ }^{6}$ But while Dracula's ontology was clear - she was a bloodthirsty foreign spirit - that of ninja was not. The reason is that knowing one's origins in no way reveals one's ontology. The dissociation between origins and ontology rests simply on the local conviction that spirits have origins just as humans do. Pak Saleh, a healer and local expert in spirits, informed me that jinn are 'like humans; they too are divided into female and male; are human-like in terms of shape and clothing; have lots of different nations (bangsa), and each nation has its own country'.

Ninja were conceived of in ambiguous terms. They could be either potent mixtures of spirit and human qualities, or singular entities of extraordinary abilities. In the latter case, ninja could be wholly spirits, or they could be humans of either Japanese or Javanese origin. It is my contention that the only way a precise ontology of ninja could be established was by testing their susceptibility to death. As Endicott (1970:55) notes, in the archipelago, the idea that any of the individual spirits inhabiting the parallel world could be killed or just die is unheard of and unthinkable. Seen in this light, susceptibility to death marks the difference between humans and spirits. People in Alas Niser trace the origins of spirits to the creation of the cosmos by Allah and believe that jinn can bear children, thus being able to reproduce themselves; for a host of other less Islamic spirits, though, there were no such beliefs. While spirits are capable of producing offspring, thus bearing one of the signs of life, they are, nevertheless, unlike humans, because they do not die. It is significant to add that spirits' immortality is basically manifested in spirit possession and counter-sorcery techniques, which achieve healing

6 In Bali, a new category of giant papier-mâché effigies called ogoh-ogoh have taken their place alongside traditional ones during the 'Day of Silence' ceremonies. While some ogoh-ogoh represent characters from contemporary Indonesian society, others portray beings such as King Kong and Godzilla, figures young Balinese know about from movies (Nozlopy 2003). 
not by the destruction of the disease-causing agent, but rather by way of exorcizing the spirit, placating it or forcing it to exit the patient's body. In agreement with Endicott, I take exorcism as evidence of spirits' immunity to death. Understood from this perspective, the ostentatious manner in which the alleged ninja's head was paraded around villages and cities was a communicative act confirming the humanness of ninja, conveying a clear message of their ontology.

In the Alas Niser area, ninja were confronted by villagers organized in ronda. Ronda are voluntary associations of unmarried youths that patrol neighbourhoods after dark (see also Siegel 1986). Before the appearance of ninja, the main purpose of ronda was to safeguard the neighbourhood against thieves. Ronda do this partly independently of the police, even though thieves are taken to the local police station after receiving a sound beating. In autumn 1998, ronda in Alas Niser were reinforced by the participation of adult married men, while their security focus was the well-being of the kyai resident in the neighbourhood. In my neighbourhood, about forty men together with the male students (santri) of the Islamic boarding school guarded the two exits of the establishment, surrounded the kyai's house, guarding doors and windows, while some others were located at the neighbourhood entrance. In other parts of the area, the safety of the kyai was of similar concern as kyai were increasingly thought to be the primary targets of ninja activity. Their houses were checked several times throughout the night, and some ronda members were permanently assigned there. Barricades were also erected in several neighbourhoods, manned by men carrying sickles and machetes.

As well as providing protection for the kyai, several ronda members sought protection for themselves. Many locals visited kyai and dukun (magic specialists), asking for invulnerability spells and talismans, and had their weapons 'filled' with ilmu. Such ilmu was said to be able to kill a person in the event of receiving even the slightest wound. The role of the spells, talismans, and ilmu cannot be overemphasized, for it was believed that ninja could not be killed using the same methods as for ordinary humans. 'In the event of an encounter with a ninja, it is ilmu against ilmu that matters: the ninja's ilmu against mine,' asserted Faisol, one of the student guards. He had a klabeh kerre (Madurese), a kind of vest with an Arabic inscription on it, worn as underwear at all times, and his sickle was 'filled' with 'ilmu Islam', he said; that is, with a spell taken from the Koran.

Ninja were constructed, therefore, as an anti-neighbourhood and antiIslamic force to be combated with the very things it was threatening to disturb and potentially destroy. Ninja were met with the sense of mutual dependency characterizing neighbourhood relations and made concrete in the institution of ronda, as well as Islam, the divine creed that protects humans from any ill-doing and from evil itself. The threat ninja posed to Islam was manifested 
both in that it was kyai who were perceived as the main targets of the attacks and in the mystical weapons villagers employed to counterattack. However, ninja attacks as rumoured, discussed, and reacted to were a more politically loaded phenomenon than the focus on neighbourhood and Islam would lead us to believe. This is because, through their rumoured successful attacks on kyai, ninja came to be viewed as articulating powerful statements about the state of the Indonesian polity and the struggle over its future direction. Before I explore these issues, it is necessary to examine the village political structure, its very convergence with Islam, and its historical roots.

\section{Centres of deference and defiance}

Within the traditionalist framework of Islam that is prevalent on the northeast coast of East Java, in which modernist formulations of the faith have made few but significant inroads, ${ }^{7}$ kyai (or kyae in Madurese) are nodes of a political structure very different from that of the modern state bureaucracy. It is first and foremost a sacred hierarchy that they participate in, and, as in all matters sacred, kyai are the object of veneration (Van Bruinessen 1995; Mansurnoor 1995). As Hefner notes, the kyai's authority is based on 'the perception of him as not merely a teacher but an heir to knowledge and power transmitted in an unbroken line from Prophet Mohammed. Consistent with this view, the offspring of the kyai were (and still are today) regarded as possessing an inborn knowledge (ilmu laduni) giving them special capacity for learning and leadership' (Hefner 2000:35). Their position as leaders is manifested in their multi-faceted societal roles, including that of religious specialists officiating at rituals, teacher/propagators of the faith, healers, moral guides, political commentators, and mediators between the (local and national) government and the local community (Mansurnoor 1990, 1992). In addition, there are the more overtly political roles some kyai take when they participate in party

7 One of the recurrent themes of such a differentiation is that traditionalist Islam recognizes the authority of ancestral custom (adat) and the authority of the Islamic legal schools, particularly the Shafiite one, in defining Islamic practice and belief in addition to the Koran and the Hadith. In contrast, the modernist position is strictly scripturalist in the sense that it relies only on the Koran and the Hadith, denying absolute authority both to other written texts and to ancestors. It is on this basis that modernists call for the purification of the faith from historical innovations and accretions, including numerous practices commonly undertaken by traditionalists. Moreover, modernists espouse an understanding of the scriptures based on the exercise of reason, emphasizing the translation of the scriptures into local vernaculars. In contrast, traditionalists focus on religious experience and the performance of religious rituals that are held to generate merit and blessings. On varieties of Islamic understanding and practice in Java and Indonesia, in general, see Beatty 1999; Bowen 1993; Geertz 1960; Hefner 2000; Telle 2000. For an excellent study of Islam's early formulations in Java, see Woodward 1989. 
politics. While most of the kyai who were politically active during the New Order were members of Partai Persatuan Pembangunan (PPP, Unity and Development Party), a government-created umbrella organization representing broad Muslim interests, after Soeharto's fall many kyai helped establish $\mathrm{PKB}$, a pro-reformasi Islamic party committed to tolerance and pluralism, which is also the political offshoot of progressive factions within Nahdlatul Ulama (Mietzner 1999).

The historical roots of kyai authority are deeply related to politics too, particularly to the effects of Dutch colonialism. Both in Java and Madura, the Dutch policy of co-opting native rulers diminished the local aristocracy's legitimacy and their power over the people, while increasing the authority of the Muslim leadership (Antlöv and Cederroth 1994:2-5; Kartodirdjo 1973; Mansurnoor 1990:28-48). In the nineteenth century Muslim leaders were often the rallying points of resistance to colonial rule during numerous peasant revolts on both islands. During the early twentieth century, though, modern secular nationalist ideology superseded Islam as a coherent vehicle for the struggle for independence. However, kyai have remained hugely influential to this day as informal community leaders.

Much of this influence stems from kyai being centres of blessing and of privileged communication with Allah. As such, they enjoy an elevated status commanding respect and deference (see also Slamet-Velsink 1994). Those locals subscribing to traditionalist understandings of the faith see kyai as a source of blessing (barokah), as caretakers of the morality of the ummat, as entrusted with the duty of propagating the faith and enhancing the orthodoxy of believers, as well as functioning as the Islamic community's main protector in the face of natural calamities and social and supernatural dangers.

In Alas Niser, as elsewhere in Java, the degree of veneration accorded to kyai is nowhere more pronounced than in the visits people pay to dead kyai in cemeteries, where they ask for their blessing. Such a blessing is thought to be manifested in the wealth, marriage partner, number of children, and knowledge one attains. It is not only dead kyai who are venerated, but living ones too. Upon encountering a kyai, villagers bow their heads and kiss his hand, while the kyai wishes them banyak rezeki (plenty, lots of prosperity). For students at Islamic boarding schools, the kyai is an awe-inspiring figure, and extreme care is taken to avoid angering him. Santri perform several tasks for the kyai and his family, and expect in return the kyai's blessing. Villagers too make regular gifts in the form of services, goods, or money to the kyai on ritual and non-ritual occasions. They keep several photos in their living room of those kyai their family is associated with, as a talisman. Moreover, the role of the kyai as master of ceremonies in all life-cycle and agricultural ceremonial meals (slametan) in Alas Niser is justified by locals in terms of the blessing he bestows upon participants and the relative ease with which the 
request (doa) he recites is thought to be received by Allah.

Such practices find linguistic expression in the category of oreng dalem, 'insiders' (Madurese), a category that in the more distant past was reserved for people of aristocratic and royal descent. Today, in Alas Niser, people belonging to this category are the ones who are in a close or intimate relationship with the kyai. The term is used to designate the kyai's wife, his sons and daughters, and relatives and affines who live in close proximity to the kyai's house and most often share the same yard (tanean, Madurese) with him. The category of oreng dalem stands in opposition to oreng, or commoners - people who cannot claim kinship or other close relationship with a kyai. The term dalem literally means 'house' in high Madurese, but it is reserved for a kyai's house, since commoners' houses are denoted by the term compok (also transcribed as compo', low Madurese). While oreng compok encompasses all those people living under the same roof, that is the members of a household, the term oreng dalem extends to a kyai's close neighbours who, in most cases, are also his relatives (including affines). The kyai's wife is addressed by the title ibu nyai, while his sons carry the title of bindara, non (both Madurese), or gus (Javanese, meaning elder brother) and his daughters carry the title of ni. I have never heard of a kyai's child being addressed by his/her name only. This would be in contravention of the respect villagers should show to oreng dalem. By being close to the kyai, they too share the kyai's potency.

While kyai command respect and influence, they are subject to constant judgment by both other kyai and their followers. Descent from a kyai is always a crucial factor in claiming kyai-ship, as well as a high level of religious scholarship: literacy in Arabic, and ability to understand and explain the Koran and other scriptures. In addition, demonstration of religious virtues such as piety, generosity, politeness, lack of self-interest, and indifference towards wealth is also crucial, as well as independence from and often defiance of state power. In the late 1990s, the latter two attributes assumed great importance. The kyai drew their legitimacy as much from their participation in a sacred order as from the lack of legitimacy of the New Order state that had failed to deliver national prosperity and was, moreover, experienced as institutionally and morally corrupt. In Alas Niser, the popular demand for kyai to be independent of state power was so strong that those kyai who had sided in the past with the Golkar Party, the New Order's state party, were referred to by the derogatory term 'kyai Golkar'. They were perceived as self-serving hypocrites who had entered a patron-client relationship with Golkar so as to receive money in exchange for votes and support of the regime. SlametVelsink (1994:51) also notes that, in the 1970s, kyai who had joined Golkar "were sneered at among santri as "the second-hand ones" or as "tigers kept in the zoo"'. In Alas Niser, such attitudes were apparent in cases where kyai, after having affiliated themselves with the government, saw their following 
reduced and their influence diminished. In contrast, the most revered kyai owed much of the respect accorded to them to their refusal to receive state funds and their defiant attitude towards government officials. ${ }^{8}$

Given the deference and respect they customarily command, how is it possible that some kyai came to be accused, assaulted, and even killed for practising black magic? Is their publicly performed piety and religious learning not a safeguard against such accusations and a proof of their benevolent nature? In short, given the social position of kyai, what was the basis of the ninja accusations? Were such accusations culturally unfounded? I do not believe this could be the case, for if the accusations had lacked plausibility and persuasive power right from the start, the ninja would not have occupied such a significant place in the popular imagination; they would be an aberration, not a menace. The fact that the ninja did more than catch everybody's attention indicates that kyai-ship might harbour a dark side. Leaving aside for the moment the identity of ninja, an issue I will turn to below, I now wish to investigate the cultural basis of these accusations, the relation between kyai and sorcery.

\section{Black knowledge and unknown hearts}

In Alas Niser, as elsewhere in Southeast Asia, sorcery is in the hands of specialists. These specialists are designated by the general term dukun santet, dukun sihir, or dhukon kemudhung (Madurese). The term dukun is also used for local healers ranging from curers to midwives (Jordaan 1985:161-94; Koentjaraningrat 1979; Nitibaskara 1993; Wessing 1996). These are people said to possess ilmu. Ilmu is generally considered to be a kind of knowledge and supernatural skill, a substantive magical power (Geertz 1960:88). There are many different types of $i l m u$, and what a particular dukun can do depends largely on the kind of $i m u$ he possesses. The most common division of $i l m u$ is that between ilmu putih (white ilmu) and ilmu hitam (black ilmu). Ilmu that helps to locate a lost object or that promotes diagnosis and cure of a disease is classified as white knowledge/power. In contrast, ilmu that makes people fall sound asleep while being robbed, that induces one to fall madly in love, or that causes illness and death is classified as black knowledge/power. In East Java, as in other Southeast Asian societies, a dukun usually possess both

8 The course of Muslim politics in Indonesia is an extremely complex issue and thus cannot be dealt with here. For detailed discussions of the New Order's relation to Islam and the kyai, and the latter's context of cooperation, as well as conflicts with the government in their changing historical trajectory, see Hefner 2000 and Watson 1994. For an account of Islamic politics in the immediate post-Soeharto era, see Mietzner 1999. 
types of ilmu, and people who are effective as healers are often said to dabble in sorcery as well.

While from a formal point of view one can draw a distinction between kyai and dukun on the grounds of kyai being learned in matters of Islam while dukun have only a limited knowledge of religion (and thus do not command the respect accorded to kyai), the reality is much more complex. Most, though certainly not all, kyai claim to possess magical powers, offer talismans and invulnerability spells, and perform healing, including healing against sorcery. Despite the fact that kyai refuse to be classified together with dukun on the grounds that they do not charge for their services (they do, however, accept gifts), they nevertheless deal with misfortune in the same supernatural manner.

In Alas Niser, several kyai claimed to be able to deal with sorcery successfully, and while privately some admitted knowing how to perform sorcery, they all denied that they had ever practised it. They asserted that performing sorcery would constitute a great sin and would ensure one would have an afterlife of punishment in hell. Similarly, local dukun took utmost care to publicly deny being sorcerers, claiming that the ilmu they possessed was entirely benevolent, and offering many of the same moral arguments the kyai did. However, villagers privately accused certain $d u k u n$ of possessing sorcery know-how. Such accusations applying to kyai, though rarely voiced, are not unheard of. I, for one, was indirectly involved in such an accusation. The accusation was levelled by the family of the kyai in whose pesantren I stayed for most of my fieldwork.

I had just returned to my quarters after visiting kyai $\mathrm{F}$. when my host, $i b u$ nyai, asked where I had been that evening. When I mentioned my visit to kyai F., she immediately asked whether I had been offered anything to drink and whether I had consumed it. I replied that I had been offered tea, a common treat offered to guests. She then turned to a friend of mine, an old santri, who had accompanied me to kyai F.'s house, angrily protesting and saying that he should have known better and tried to dissuade me from going since kyai F. was not a good man, was a dukun, and could have poisoned me. In these cases, poison (racun) is a euphemism for sorcery. My friend later explained that my host family was in conflict with kyai F. because of the latter's having offered religious instruction to children in the area, thus taking potential students away from my host family. The rivalry had led, quite unusually, to a public confrontation, and since then the two families had avoided contact with each other. My friend also explained that I could well have been a victim of kyai F.'s ilmu as a way of taking revenge, since my death would have caused my host family a great deal of trouble with the authorities.

This might well have been an isolated and non-typical case of inter-kyai rivalry but for the fact that another villager had reiterated a similar, though 
more indirect, accusation against a kyai he refused to name. Pak Sutam, a construction supply shop owner in his late fifties, told me he had once been the victim of 'black ilmu'. A client had paid him a large sum of money which he stored away in a secret place. When he looked for it two days later, he could only find four locusts. Suspecting that there was a relation between the locusts and the money, he took the insects to a kyai. The kyai informed him that the money was infused with ilmu hitam that allowed it to be turned into locusts, hereby facilitating the money's speedy return to its owner. The kyai informed Pak Sutam that he could take revenge (beles in Madurese, literally 'to reply', 'to reciprocate') if he wanted; the kyai could make sure that by killing the four locusts with his superior ilmu, the locusts' owner would suffer - if not death, at least grave illness. Pak Sutam declined the offer, saying that accepting it was inappropriate for people who take seriously their Islamic faith. His comment implicitly accused the kyai of contravening religious rules and being willing to practise sorcery for the right amount of money.

Sorcery accusations, made in private, out of the public domain, and indirectly, are very much in keeping with the general tenor of East Javanese village life (Geertz 1960; Koentjaraningrat 1979). Villagers value consensus and harmony in their relationships with others, and though they do everything possible to prevent an argument from developing into an open confrontation, they do not always succeed. Ideally, public behaviour should be regulated by a calm heart (hati tenang), religious piety (imam), and respect (hormat) towards one's superiors. This last injunction makes it imperative for people to be extra careful about accusing a kyai of possessing sorcery power. On the other hand, villagers always raise doubts about anyone's keikhlasan (sincerity), asserting that one can never truly know another person's heart (hati). Keikhlasan refers to the motives of human behaviour that reside in one's heart, and postulates that all behaviour should be motivated by the sincere desire to serve Allah and obey his revelation and not by more mundane concerns such as the acquisition of wealth, praise from others, or status. As such, keikhlasan marks a distinction between outer appearances and inner reality, between performance and feelings or thoughts, and forms the conceptual basis of a social criticism against others, even when their actions are in accord with normative piety. ${ }^{9}$ But since one can never be sure about other people's intentions, one should abstain from accusing them publicly. Such is the uncertainty surrounding other people that, in most cases, doubts are rarely voiced publicly. They are, rather, kept in one's own heart. This cultur-

9 Wikan (1987:338) notes a similar uncertainty among the Balinese when she writes that 'behind a surface of asceticism, grace, and gaiety, we found social uneasiness, great concern with the individual thoughts and intentions of others, and ubiquitous fear. Fear not so much of the gods or demons, but of fellow human beings'. 
ally enforced restriction leaves the public domain largely unaffected by the inherent ambiguity associated with social others, as well as the disturbing power of sorcery accusations.

However, it happens from time to time that doubts and accusations break out of their cultural fences, and what ensues is violence. Dukun who are openly suspected of practising sorcery have their houses attacked and destroyed by their neighbours and co-villagers. Sometimes this is followed by an order to leave the kampung. In a few cases, neighbours beat suspected sorcerers to death. I was told that, some months before I arrived in Probolinggo, such an attack was carried out in the town against a fisherman. Enraged neighbours, suspicious of his recent and sudden acquisition of wealth and public knowledge of his possession of ilmu that healed people, stormed his house, dragged out the fisherman and his family, destroyed walls and furniture, and painted on the outer walls 'compok dhukon santet' (sorcerer's house, Madurese). The man and his family were not physically harmed, but, in fear of their lives, they were forced to move to another village, leaving behind their house, which still bore signs of the outrage. Instances of anti-sorcery violence were described to me as being sporadic; such violence does not culminate in a killing spree, or a witch-hunt extending beyond the community; rather, it is an issue among neighbours who, threatened by the presence of a sorcerer in their midst, take measures to physically eliminate the evil he/she represents. In this context, the victims of violence and their murderers are known to each other, as they live in a small community. In such cases, too, violence is carried out by a crowd that, to the police's puzzlement, claims collective responsibility for the attacks or keeps an eerie silence of complicity. In addition, such violence, to the best of my knowledge, is rarely or not at all directed against kyai. ${ }^{10}$

Anti-sorcery violence can be stopped from erupting through recourse to Islam. Sumpah pocong, an oath of innocence, is applied in cases of legally unresolved serious crimes such as murder and sorcery (see also Ghazi 1999). The oath, usually performed in mosques and sometimes in pesantren, is administered by a kyai. The suspected murderer or sorcerer is first wrapped in a shroud (pocongan, Javanese) of unbleached cotton, in the same way corpses are wrapped. In a place of worship, the participants - the suspected man's relatives and neighbours - perform shalat jenazah, the funeral ritual prayer, for the suspect in the same way they do for corpses. The kyai then places a

10 The only case I have come across of a kyai being attacked and killed on suspicion of practising sorcery is related in Van Dijk's account (2001). During the ninja killings, a kyai in Demak on the northern coast of Java was beaten to death by his fellow villagers on the grounds of having 'boasted that he had caused the death of people by supernatural means' (Van Dijk 2001:364). Such public boasting is most unusual, to say the least, not only because it comes from a kyai, but primarily because anyone possessing ilmu takes good care to dissociate himself/herself from the practice of sorcery, in public at least. 
Koran on top of the suspect's head and recites the oath, which is repeated by the suspect. The ritual lasts only ten to fifteen minutes, but its consequences in case of perjury are said to be grave. 'Insyallah, the perjurer will not live long, he/she will face death within forty days [...] besides that, the perjurer will see all his/her possessions vanish and will live the remainder of his/her time in great suffering, for he/she has caused immense suffering to other people', a villager who once witnessed such an oath told me. ${ }^{11}$

\section{The revenge of signification: remembering}

Sorcery as people in Alas Niser conceive of it is directed against persons with whom one is closely related on an everyday basis (see also Koentjaraningrat 1985:419). Geertz (1960:110), writing about sorcery in Modjokuto in the 1950s, notes:

[It] tends to be practiced on neighbors, friends, relatives and other acquaintances fairly close at hand. Of course, the dukun employed may be a distant one and so be attacking someone far away from where he is performing his rite, but the actual instigator of the deed [the sorcerer's client] is always someone near at hand. Unlike some other peoples, Javanese do not accuse outsiders of sorcery.

Similarly, an accusation against a suspected dukun is a neighbourhood issue. Sorcerers place their neighbours in grave danger, for the ilmu they possess is believed to demand victims on a regular basis. At a time when a sorcerer's business is suffering from lack of clients, his/her neighbours are thought to be prime potential victims of ilmu's hunger. Sometimes, such suspicions escalate into violence. When violence breaks out, it is perpetrated by neighbours against a neighbour. Such violence remains enclosed in the kampung and does not spread outside community boundaries. Equally, the oath of innocence is performed among neighbours who, resorting to divine power, become the witnesses of divine justice against a co-resident whose activities are believed to be putting them in danger. As for kyai, by virtue of the deference accorded to them due to their position in the sacred hierarchy of piety and learning, they stand for the containment of violence and evil. However, certain kyai, especially those who have dealings with spirits and the invisible world, raise some degree of suspicion, since they too may succumb to temptation and make a pact with an evil spirit (or evil regime) so as to attain material wealth.

11 The Nahdlatul Ulama report notes that sumpah pocong during the time of the ninja killings had not only lost its efficacy but now worked so as to increase the potency of the sorcerer undergoing the ritual (LAKPESDAM-NU 1999:16; Campbell and Connor 2000:80). I did not come across any such inversions in my area of research. 
Nevertheless, human motives are taken to be well hidden from public view and others can never really know about them. It is exactly for this reason, and the deference of course, that accusations against a kyai are rarely voiced.

Where does all this leave us with respect to ninja and the killing spree they were rumoured to have perpetrated? For one thing, ninja were non-locals, strangers who took extreme care to hide their identities and who perpetrated a new type of violence against people with whom they had no relationship. The ninja killing spree was, moreover, trans-local, for ninja were thought to use deceit or special powers to travel long distances, and similar cases were reported from areas as far as Banyuwangi and Semarang. In addition to the rapid spread of violence over a vast area and the absence of a relationship between victims and ninja, two further characteristics of the ninja attacks deviate from established patterns of anti-sorcery activity. Usually, violence against suspected sorcerers tends to be both an open, public event and a collective activity. In contrast, ninja acted as delegated assassins and in secret, often at night. Moreover, the apparent similarity in their mode of operation was evidence of patterns of organization and coordination that are not found in cases of neighbourhood anti-sorcery activity. These factors seem to me to have led locals of Alas Niser to dissociate the ninja attacks from punishment for the practice of black magic. In trying to establish the identity of ninja and the reasons behind the attacks, locals had to look to another plane of social life.

The people of Alas Niser flocked to protect the kyai for two reasons. As a primary source of blessing and communication with Allah, kyai serve as one of the necessary means for the production and reproduction of a moral society. By protecting the kyai, people of Alas Niser and other areas sought to maintain their societal order, for a society without kyai propagating the faith and exhorting moral behaviour would be a regression to an unregulated, natural state of unconstrained passions (nafsu). The second reason locals sided with the kyai in the face of ninja accusations of practising sorcery is that the acts of ninja failed to register in the popular imagination as legitimate. As Nagengast (1994:115) notes, 'legitimacy is always a central concern in the sense that violence is only violence by definition if the perpetrators fail to establish the legitimacy of their acts against claims of others that it is illegitimate' (see also Riches 1986).

Seeing the ninja killing spree within the broad, national context of Indonesia's political and economic woes of the late 1990s, it must be noted that the spree was intended primarily as purification and restoration. Its violence assigned some of the blame for the country's economic and political crisis on certain individuals whose alleged knowledge of and capacity for performing evil spells had brought misery and despair to people's lives. Sorcerers had brought Indonesia to its knees, was the statement the ninja killings made. By physically eliminating dukun and kyai, ninja were presenting themselves as the primary agents of restoring Indonesia's economy and polity to some degree of 
stability, thus doing 'the people' (rakyat) a big favour similar to the situation in 1965-1966 when the Partai Komunis Indonesia (PKI, Indonesian Communist Party), 'public enemy number 1 ' of that decade, was violently eradicated. However, the politically loaded ninja killings did not persuade locals that dukun and kyai were creating national chaos by means of mystical arts. The lack of legitimacy of ninja violence was the consequence of the novelty of its actors and its nonconformity to established patterns of anti-sorcery activity. ${ }^{12}$

It was precisely the lack of legitimacy attached to ninja acts that prompted my search for the reasons behind the violence. That search centred on looking at different kinds of violence and converged on issues of 'rightfulness'. Seen in this context, the exercise of non-intimate, secretive, and translocal violence was attributed by my interlocutors to the New Order state. In late 1998, several months after Soeharto's fall from power, villagers were less reluctant to openly air their criticisms against the regime, taking advantage of some of the breathing space Soeharto's resignation and the reformasi movement had created. They explained their decades-long avoidance of open political criticism by fear of the force it would have been met with. Speaking against the New Order before Soeharto's fall was associated with being harassed by police, arrested, and convicted. It was no time for heroes, they asserted, for they all had had families to support. The police and the army, whose presence was deeply felt in Alas Niser since it was the site of Komando Rayon Militer (KORAMIL), military headquarters at the district level, were seen as the most important institutions of the New Order state, along with the bureaucracy. While the bureaucracy was seen as corrupt (extorting money from the populace) and alien (since none of the top civil servants were locals), both the army and the police were especially singled out as being hostile to local communities.

Echoing claims made at the national level by many pro-reformasi organizations and reform-minded intellectuals, locals maintained that the Indonesian army, in the absence of external threats posed by neighbouring states, constructed 'the people' (rakyat) as the enemy of the state, and perceived the army's role as safeguarding the state from its citizens. The state, in a way, belonged only to its functionaries. Sutrisno, an onion trader, airing this general attitude, argued that 'the army takes the rakyat for its enemy [...] it uses its weapons so as to exterminate them, it does not hesitate to kill innocent people. Given the slightest opportunity, soldiers just pull the trigger.' In nar-

12 Siegel (2001:41), in his analysis of witch-hunts in East Java, makes a similar case. A great deal of his argument rests on the 'new type of witch' these later killings produced, for they too departed starkly from customary modes of counter-action. But while Siegel's 'new' witches were the outcome of the collapse of structures of identity generation the New Order had erected, in my case the lack of legitimacy of ninja violence was the result of its assumed continuity with the practices of the New Order state. 
ratives about the use of excessive force, the police appeared alongside the army. Much despised for extorting bribes, policemen were also said to use unnecessary, arbitrary, and excessive force.

Villagers traced the New Order's association with violence to its very birth, and saw the New Order as inherently violence-based. In the late 1990s, and especially after his resignation, questions began to be raised over the transfer of power from Soekarno to Soeharto in 1966 and Soeharto's ascendancy to power in the midst of anti-communist massacres. Following his resignation, Soeharto became the target of numerous calls for investigations into scandals, mainly financial ones, and acts of repression carried out during the 32 years of his rule, some of the scandals going back to the days when, as a young general, he assumed control of the army and dedicated himself to crashing the ' 30 September Movement' communist coup. According to the official version of the events of 1965-1966, Soeharto was the hero who had saved Indonesia both from a president who had come to rely too heavily on communist support and from the PKI, since he had almost single-handedly put down the red menace. It was this official version of events that many Indonesians both on the national and the local scene were contesting. ${ }^{13}$

As Robinson (1995:280) writes, the events of 1965 are better understood as two coups: the ' 30 September Movement' led by an army lieutenant colonel, and Soeharto's counter-coup. The first involved the execution of six highly placed generals and the formation of a 'Revolutionary Council'. The second, led by Major General Soeharto, crushed the ' 30 September Movement' after portraying it as a treacherous plot against the nation, instigated by the PKI. Soeharto then ordered the physical annihilation of alleged PKI members and sympathizers, in a bloody campaign of massacres carried out by an alliance of military units, vigilante gangs, and civilian support offered by other secular and Muslim political parties and organizations, among which, in Java, Nahdlatul Ulama had a prominent role (Cribb 1990; Young 1990; Langenberg 1990; Hefner 1990:193-227).

In the wake of the ninja killings, some locals in Alas Niser were willing to talk voluntarily about the anti-communist massacres, thereby departing from the general reluctance and silence usually surrounding those events

13 Budiawan 2000; Van Dijk 2001:217-8; Zurbuchen 2002. Both Budiawan and Zurbuchen provide succinct accounts of the range of popular, literary, and academic publications of this period that raised very important questions about the events of 1965, contributing to a growing uneasiness about official history. For example, the now-defunct newsweekly $D \mathcal{E} R$ published several critical articles in September and October 1998, the time of the ninja killings, and the prominent Tempo continued to apply pressure with articles published throughout the following year (Zurbuchen 2002:569-71). The weekly Oposisi (1999) joined in with an article carrying the title 'Was Soeharto really the mastermind of G30S/PKI?'. 
(Beatty 1999:217; Siegel 1998:117). My interlocutors were people who admitted to having participated (some more actively than others) in the arrests and killings of suspected communists in the area. In contrast to the official version, they asserted that both coups actually had a single source; they were both masterminded by the same man, Soeharto. In retrospect, and with noticeable anger, they accused Soeharto of deception. Soeharto, their story went, had first sided with the communists and organized the '30 September Movement'. Subsequently, however, he re-aligned himself with anti-communist forces, and led the arrest and the killing of the coup's alleged leaders. In their narratives, Soeharto was the main actor responsible for the killing spree of several hundred thousand alleged communists ${ }^{14}$ all over the Indonesian countryside, since locals attributed their own participation in the killings to having been fooled by Soeharto's hypocrisy.

Echoing similar comments made by other informants, this is how Pak S. put it to me in a conversation held at his house in the presence of several of his male relatives: 'It was Soeharto who caused [the killings]. He thought that if all the other generals were to die, he would be the only one left. That's why he was the one who later became president [...] for if the other generals had not been eliminated it would have been one of them who would have succeeded Soekarno. [...] Indeed, the instigator of the whole thing was Soeharto. He pretended that he had not had anything to do with the '30 September Movement' and had all the other generals killed. Then he pressed Soekarno to hand over the mandate to rule the country. People back then were just stupid (bodoh) [...] no one realized that he was the one who orchestrated everything. He won't admit it. He just lies.'

In Alas Niser, as elsewhere in Java, Islamic youth organizations associated with Nahdlatul Ulama were at the forefront of the anti-communist killings, and local kyai did much to initiate, identify, and lead the arrests and murders of locally known or suspected communists, sometimes cooperating with army units, sometimes working independently. Indeed, several of my informants referred to the time of communist killings as a time when 'Nahdlatul Ulama justice' ruled. This 'justice' consisted of night raids on houses of suspected communists, the operation of detention centres where torture was used, and the eventual killing of an unspecified number of suspected communists, all carried out by local kyai and Nahdlatul Ulama 'mobs', largely on the basis of lists that had been previously compiled. As Hefner (1990) notes, Muslim leaders' hostility to PKI can be traced both to the fact that members of PKI were

14 Accounts of the cost of the massacres in terms of the number of lives lost differ. A government study in 1965 estimated that 78,500 people had been killed, while a military mission in 1976 put the number at 500,000. For difficulties in identifying how many people were actually killed and the identity of the killers, see Cribb 1990:6-14. 
Hindus or non-practising Muslims (abangan), and to the fact that the land redistribution scheme that the PKI pursued so relentlessly in the years leading up to 1965 undermined the economic interests of kyai, most of whom were (and still are) among the wealthiest strata by village standards.

Memories of the 1965 killings often disturbed the sleep of Pak M., a male informant in his late fifties. He admitted to having been a witness to the decapitation of several alleged communists carried out in an undisclosed location near Alas Niser. According to his account, the arrested men had their hands tied behind their backs, and were made to kneel while the sword of the executioner - a co-villager he did not refrain from naming - delivered the fatal blow. Their bodies were then dragged away and placed in an unmarked mass grave. These images, he said, haunted his sleep, and despite his best efforts, they had not gone away. Under the burden of such memories, he once asked the advice of a kyai who had been actively involved in the 1965 events. Without much regret, the kyai replied that those who had contributed to the defeat of atheists were destined for Paradise. As for those who had capitalized on the uncertainty and used it to take personal revenge against innocent people, they would meet due punishment in the form of an afterlife in Hell. Even though he never described himself as anything more than a witness standing several metres from the place of execution, it seems to me, for reasons I cannot go into here, that the spectre of Hell had added further strains to Pak M.'s distressed nights.

A similar kind of uneasiness and a need for resolution lies at the core of the comment made by Pak S.: 'People back then were just stupid'. Pak S. used the term bodoh to describe that stupidity. Bodoh carries the meaning not so much of a mental disability but primarily, as Siegel (1998:66-7) notes, of a lack of the capacity to behave appropriately due to deficient understanding. Deficient understanding leads one to behave not only improperly but also in a way that others find difficult to make sense of or to accept. However, a bodoh person carries only limited responsibility for his/her wrong acts, for if he/ she had understood more, he/ she would have acted rightly. In this case, that would mean not having been fooled by Soeharto's power scam and having abstained from the massacres.

Revisiting and reconfiguring the past lies at the heart of local interpretations of the ninja killings. The New Order's heavy reliance on excessive force $^{15}$ and Soeharto's destabilizing-through-terror ascent to power in 1965

15 My analysis here of the New Order's utilization of terror is necessarily discontinuous in historical terms. One could add several other cases, including the Petrus killings of the 1980s (Barker 1998; Pemberton 1994:311-8; Siegel 1998). However, such cases did not feature in the ninja narratives I collected; the narratives themselves were selective. This does not of course preclude another sort of analysis such as Schulte Nordholt's (2002) which privileges historical continuities. 
were among the main resources locals drew upon in construing ninja as paramilitaries in the service of Soeharto and his allies who, resorting to timehonoured tactics, aimed at staging a comeback through the spreading chaos, the instigation of accusations, and erosion of the trust characterizing relations among neighbours and those between peasants and Muslim leaders. The parallel between the communist massacres and the ninja killing spree is well articulated in the observation made by Pak Asni, a neighbour of mine, commenting that 'in 1965, it was Soeharto against the communists; now it is Soeharto against the kyai'.

Local responses to the ninja killings both necessitated and facilitated a new politics on the national level. While in 1965, Muslim parties and their affiliates had lent their support to the establishment of the New Order, in 1998, after years of disillusionment and partial co-optation, they began to publicly challenge the legitimacy of the regime. The popular ideal of a kyai as an independent leader achieved its full force with the establishment of PKB, created by the leader of Nahdlatul Ulama and other kyai in July 1998. The very real threat this party posed to the New Order was seen some months later when, in the national elections, PKB came first in the province of East Java. Five months later, the national assembly elected as president of the republic Abdurrahman Wahid, one of the founders of the party, who is grandson of a kyai and a kyai himself.

During Abdurrahman Wahid's presidency, the reconstitution of the 'truth' about the events of 1965 briefly gained momentum. In March 2000, Wahid took the unprecedented step of issuing an apology for the role played by Nahdlatul Ulama affiliates in the killings of alleged communists, and made a public appeal for an investigation of the killings, as well as of other human rights violations under the New Order (Kompas 2000). However, when he went as far as suggesting the revocation of the ban on Marxism/Leninism (Decree 25/1966), a wave of negative reactions ranging from anti-communist demonstrations in Jakarta and uneasiness among certain factions of Nahdlatul Ulama to the blocking of the parliamentary debate, delivered a severe blow to efforts to reclaim the past for a democratic present. As Zurbuchen (2002:573) writes, 'the public process of coming to terms with the legacies of 1965 thus lost its earlier focus on recovering history and was readily subsumed within familiar polarizations: left vs. right, communism vs. Islam'. However, all was not lost. In September 2004, the country's parliament agreed to set up a 21-member Truth and Reconciliation Commission, with a mandate to investigate gross human rights violations from Indonesia's founding in 1945 to the present day. Though the powers of the Commission are severely limited, its establishment is nevertheless a significant step towards providing a space for new histories to emerge. What sort of histories will be narrated and sanctioned, and how far they will go towards accommodating multiple perspectives, remains to be seen. 


\section{Conclusions}

Writing about Indonesian society in the 1980s, Siegel (1998) observes that fear of retaliation for the violence against communists has permeated New Order politics and focused minds on imaginary enemies. Despite the fact that survivors of the massacres of 1965 have only recently started to claim their own version of history, the fear of communism, Siegel continues, has been perpetuated as a fear of other spectres. In particular, he notes: 'Indonesians think it necessary to respond to something they feel inhabits Indonesian society and that cannot be identified. Sometimes this fear is refracted through criminals, such as those massacred in 1983 and 1984, other times through communists, or still others.' 16 In late 1998, this deep uneasiness about the past (and uncertainty over the future) took the form of ninja. However, in what can be seen as the revenge of signification, this fear of spectres was turned on its head, so to speak, and through subversive narratives of political discontent, a new source of menace was identified. The critical chain symbolically linking the New Order with protection against the ghosts of history (that is, communists) was broken and its architect was named as a terrorist, both in the present (1998) and the past. The New Order and Soeharto were now linked with the forces of disruption and death, as localities defined by their allegiance to divine-like centres of deference reclaimed the right to exercise force. In other words, ninja-combating localities such as Alas Niser appropriated the power of the state to use violence and formulate authoritative versions of the past, turning themselves into agents of state making and narrators of alternative histories.

Violence and rumours of murderers lie at the intersection of the local and the national, defining and conditioning their entanglements. Both the terror that spectres inspire and the narratives in which they are embedded have a profound history of prior entanglements as current cases of violence are construed through reference to the constraints of a shared past and the possibilities of diverse futures. They are also intricately woven into long-standing cultural formations of meaning and have, in turn, the capacity to create meanings and consciousness anew. My aim here has been to interrogate the discursive production of meaning of the ninja stories, paying attention to the 'webs of significance' my interlocutors have spun and to follow the connections and disconnections they have established, so as to understand how rumours of terror and fearful spectres relate to social action and political change.

The activities of ninja in Java created what Taussig $(1984,1987)$, in his seminal treatment of violence in the Putumayo area of the Amazon, calls the

16 Siegel 1998:6. For the fear criminals inspired and the government's actions towards them in the 1980s during the Petrus killings, see Barker 1998; Pemberton 1994:311-8; Siegel 1998. 
'space of death'. The space of death, as described by Taussig, is an atmosphere of acute fear produced through the massive staging of excessive punishment and torture, and a form of subjectivity achieved by people's being subjected to activities which, although they stop short of killing, inflict immense agony in an effort to ensure long-lasting subordination. Taussig's account of the horrific excesses of European colonizers emphasizes its all-pervasive impact on the lives of Putumayo Indians and their tormentors alike, stressing how the 'space of death', both in early twentieth-century Putumayo and in more recent histories of Latin American dictatorships, cripples people's capacity to resist, erodes trust, suppresses social interaction, and leads to solitude, paralysis, and silence (see also Green 1994; Perelli 1994; Skidmore 2003). At the same time, he sees in the 'space of death' the potential of a politics of transcendence. 'Yet', he writes, 'this space of death is preeminently a space of transformation: through the experience of coming close to death there may well be a more vivid sense of life; through fear can come not only a growth in self-consciousness but also fragmentation, then loss of self conforming to authority; or, as in the great journey of the Divine Comedy with its smoothly cadenced harmonies and catharsis, through evil, good' (Taussig 1987:7). Through fear and terror, I may add, can also come retribution, resolution, and transformation, however historically incomplete and socially partial all these might be.

In Java, the terror that the murders created, and the rumours of imaginary enemies the ninja gave rise to, are to be understood by examining the articulation of the local and the national. In contrast to a recent influential account on ritual murders and 'fantastic' enemies, I have claimed that such phenomena cannot necessarily be understood as translocal metaphors that explain and express discontent with globalization and millennial capitalism. Writing with respect to the proliferation of witchcraft accusations, ritual murders, and rumours of body parts theft in post-apartheid South Africa, Comaroff and Comaroff $(1993,1999)$ observe that similar stories are on the rise in the rest of Africa, Latin America, and Eastern Europe, and attribute this intensification to the way millennial capitalism is experienced globally. The seemingly translocal character of such rumours and fears is thus tied, in the Comaroffs' account, to assumed similarities in the political economy of such places - that is, 'the penetration of millennial capitalism and the culture of neo-liberalism' - which, in turn, give rise to a global common language that attempts to explain the mechanisms of the market through reference to the occult and the mystical arts. 'For our own part, we do not see it [the belief that the supernatural is primarily involved in the production of wealth] as an isolated, even as an African phenomenon', they write. 'In a surging, implosive economy, it is just one element popping up in comparable contexts all over the planet, albeit in a wide variety of local guises' (Comaroff and Comaroff 1999:284). Although my concerns here are not related to rumours 
of attaining quick wealth and the fear of people who do so by allegedly employing mystical arts, I have demonstrated the complex ways in which the intensification of sorcery accusations and ritual killings in Java are fragments that make sense within worlds of a more intimate scale. Though global factors such as the economic crisis of 1997 and the devastating impact it had on the middle classes, the urban poor, and the peasants are very much part of the wider context in which the ninja made their appearance in Java, the causative trajectory Comaroff and Comaroff (1999) postulate between local experiences, expressive language, and a single translocal political economy does not in this instance carry much explanatory power.

Understanding the political implications of rumours, fear, and killings necessitates looking at the way that cultural formations of meaning are employed by competing actors (see also Margold 1999). Seen from my informants' perspective, ninja acts played upon culture in the sense that they sought to capitalize on inherent ambiguities attached to the position of dukun and kyai and to initiate new modes of punishment by emulating existing ones. Doubts about the sincerity and inner motives of kyai and dukun were magnified so that popular discontent about the economic crisis and political instability would be directed against them and not against the New Order. On the other hand, the deep significance locals attribute to birth and origins as an indication of a person's character was drawn upon to lend support and persuasive power to assertions that New Order figures, and Soeharto in particular, were once again plotting a bloody comeback. The imagery of the dhalang, the puppet master who, in the traditional shadow theatre, controls the puppets' speech and interactions from behind the screen, was invoked time and again to explain and render meaningful such plotting.

Embedded within practices that employ culture as a resource, local ways of making sense of spectral violence rest ultimately on popular semiotics. My interlocutors' movement from initial puzzlement, fear, and lack of understanding of the perpetrators of the killings gave way to firm conviction as to the identity of the ninja and their political motives through a recognition of signs. Images derived from modern celluloid iconographies of power revealed clues as to ninja modes of behaviour, press photos of decapitated ninja corpses provided evidence of their ontology; mobility of ninja, their translocal scope of operation, and use of excessive force aligned them with the army. Historical conjuncture and the timing of the events also played a role in creatively deciphering intentions on a grand scale. These were all combined with common knowledge of the distinctive features of kyai and sorcerers. The interpretative process that makes truth out of rumours is a political act. It seeks to create actors or speakers who judge the use of power and control its distribution, and who, in the final analysis, articulate and construct reality itself. 


\section{Acknowledgments}

The fieldwork for this article was conducted between October 1998 and March 2000 and was funded by a scholarship from the Greek State Scholarship Institute. The writing was undertaken during the tenure of a Leach/RAI Fellowship at the University of Sussex, Brunel University. I presented earlier versions of this article at the 2003 Conference of the Association of Southeast Asian Studies UK in Leeds, and the staff seminars of the departments of anthropology at the University of Sussex and the School of Oriental and African Studies, University of London. I would like to thank all participants at these three occasions for their comments and criticisms. I would also like to thank Janet Carsten, Dimitri Tsintjilonis, Thomas Hansen, Robert Hefner, Mike Poltorak and Geert de Neve for commenting on earlier drafts and the anonymous BKI reviewers for their comments and suggestions. The usual disclaimer applies here too.

\section{References}

Aditjondro, George

2000

'Ninjas, nanggalas, monuments, and mossad manuals; An anthropology of Indonesian state terror in East Timor', in: Jeffrey A. Sluka (ed.), Death squad; The anthropology of state terror, pp. 158-88. Philadelphia: University of Pennsylvania Press. [Ethnography of Political Violence.]

Antlöv, Hans and Sven Cederroth

1994

'Introduction', in: Hans Antlöv and Sven Cederroth (eds), Leadership on Java; Gentle hints, authoritarian rule, pp. 1-32. Richmond: Curzon. Barker, Joshua

[Nordic Institute of Asian Studies, Studies in Asian Topics 16.]

1998 'State of fear; Controlling the criminal contagion in Suharto's New Order', Indonesia 66:6-42.

Beatty, Andrew

1999

Varieties of Javanese religion; An anthropological account. Cambridge: Cambridge University Press. [Cambridge Studies in Social and Cultural Anthropology 111.]

Bowen, John R.

$1993 \quad$ Muslims through discourse; Religion and ritual in Gayo society. Princeton NJ: Princeton University Press.

Brown, Jason

2000

'The Banyuwangi murders', Inside Indonesia 62 (April-June 2000), http: / / insideindonesia.org/artindex.htm. 
Bruinessen, Martin van

1995 'Tareket and tarekat teachers in Madurese society', in: Kees van Dijk, Huub de Jonge and Elly Touwen-Bouwsma (eds), Across Madura Strait; The dynamics of an insular society, pp. 91-118. Leiden: KITLV Press. [Proceedings 2.]

Budiawan

2000

'When memory challenges history; Public contestation of the past in post-Suharto Indonesia', Southeast Asian Journal of Social Science 28:3557.

Campbell, Caroline and Linda Connor

2000 'Sorcery, modernity and social transformation in Banyuwangi, East Java', Review of Indonesian and Malaysian Affairs 34:62-97.

Comaroff, Jean and John Comaroff

1993 'Introduction', in: Jean Comaroff and John Comaroff (eds), Modernity and its malcontents; Ritual and power in postcolonial Africa, pp. xi-xxxvii. Chicago: University of Chicago Press.

1999 'Occult economies and the violence of abstraction; Notes from the South African postcolony', American Ethnologist 26:279-303.

Cribb, Robert

1990 'Introduction; Problems in the historiography of the killings in Indonesia', in: Robert Cribb (ed.), The Indonesian killings of 1965-1966; Studies from Java and Bali, pp. 1-43. Clayton VIC: Centre of Southeast Asian Studies, Monash University. [Monash Papers on Southeast Asia 21.]

2000

'From petrus to ninja; Death squads in Indonesia', in: Bruce B. Campbell and Arthur D. Brenner (eds), Death squads in global perspective; Murder with deniability, pp. 181-202. London: Macmillan.

Das, Veena (ed.)

$$
\text { Murder with deniability, pp. 181-202. London. Macmillan. }
$$

1990 Mirrors of violence; Communities, riots and survivors in South Asia. Delhi: Oxford University Press.

Drake, Richard Allen

1989 'Construction sacrifice and kidnapping rumor panics in Borneo', Oceania 59:269-79.

Dijk, Kees van

2001

A country in despair; Indonesia between 1997 and 2000. Leiden: KITLV Press. [Verhandelingen 186.]

Ellen, Roy

2002

'Nuaulu head-taking; Negotiating the twin dangers of presentist and essentialist reconstructions', Social Anthropology 10:281-301.

Endicott, Kirk Michael

1970 An analysis of Malay magic. Oxford: Clarendon Press. [Oxford Mono-

Erb, Maribeth graphs on Social Anthropology.]

1991 'Construction sacrifice; Rumors and kidnapping scares in Manggarai', Oceania 62:114-26.

Geertz, Clifford

1960 The religion of Java. Chicago: University of Chicago Press. 
George, Kenneth M.

1996 Showing signs of violence; The cultural politics of a twentieth-century headhunting ritual. Berkeley CA: University of California Press.

Ghazi, Imas

1999

'Sumpah pocong, tradisi religi yang sakral (1), (2), (3), (4-habis)', Jawa

Ghosh, Anjar Kumar

Pos, Radar Bromo, November.

$1998 \quad$ Partial truths; Rumor and communal violence in South Asia, 1946-1992. $\mathrm{PhD}$ thesis, University of Michigan.

Goldstein, Daniel

2003 '"In our own hands"; Lynching, justice, and the law in Bolivia', American Ethnologist 30:22-43.

Gordillo, Gastón

2002 'The breath of the devils; Memories and places of an experience of terror', American Ethnologist 29:33-57.

Green, Linda

$1994 \quad$ 'Fear as a way of life', Cultural Anthropology 9:227-56.

Hefner, Robert W.

1990 The political economy of mountain Java; An interpretative history. Berkeley CA: University of California Press.

2000 Civil Islam; Muslims and democratization in Indonesia. Princeton NJ: Princeton University Press. [Princeton Studies in Muslim Politics.]

Hoskins, Janet

1996 (ed.) Headhunting and the social imagination in Southeast Asia. Stanford CA: Stanford University Press.

2002 'Predatory voyeurs; Tourists and "tribal violence" in remote Indonesia', American Ethnologist 29:797-828.

Howe, Leo

1999-2000 'Describing the Balinese; Sorcery, fear and laughter', Cambridge AnthroHusson, Laurence pology 21:37-61.

$1995 \quad$ La migration maduraise vers l'est de Java; Manger le vent ou gratter la terre? Paris: L'Harmattan. [Collection Recherches Asiatiques.]

Indonesian Observer

1998a 'Doubt mounts over murder spree charge', 22 October.

1998b 'Wiranto calls for calm amid terror', 23 October.

1998c 'Kontras claims mass killings organised', 24 October.

1998d 'Reconcile, not revenge: Cak Nur', 24 October.

Jakarta Post

1998a 'Two more alleged "ninjas" die at the hands of mobs', 12 November 1998.

1998b 'More "ninjas" killed by mobs', 22 November.

Jawa Pos

$1998 \mathrm{a}$

'Ketika Banyuwangi menjadi lading pembantaian "tukang santet" (3);

Leher diikat, diseret motor, tetap hidup', 10 October.

1998b 'Kena kanker, dituduh kena santet mahfud', 13 October.

1998c 'Ketika Banyuwangi menjadi lading pembantaian "tukang santet" (4);

Kena batunya, klenger di tangan kyai', 14 October. 
Jordaan, Roy Edward

$1985 \quad$ Folk medicine in Madura (Indonesia). PhD thesis, University of Leiden. Kammen, Douglas

2001 'The trouble with the normal; The Indonesian military, paramilitaries, and the final solution in East Timor', in: Benedict R.O'G. Anderson (ed.), Violence and the state in Suharto's Indonesia, pp. 156-88. Ithaca NY: Southeast Asia Program Publications, Cornell University. [Studies on Southeast Asia 30.]

Kapferer, Jean-Noël

1990 Rumors; Uses, interpretations, and images. Translated by Bruce Fink. New Brunswick NJ: Transaction. [Originally published as Rumeurs; Le Kartodirdjo, Sartono plus vieux média du monde, Paris: Seuil, 1987.]

$1973 \quad$ Protest movements in rural Java; A study of agrarian unrest in the 19th and Koentjaraningrat early 20th centuries. Kuala Lumpur: Oxford University Press.

1979 'Javanese magic, sorcery and numerology', Masyarakat Indonesia 6:3752.

$1985 \quad$ Javanese culture. Singapore: Oxford University Press.

Kompas

1998 a

$1998 b$

'Termakan isu "ninja", massa mangamuk di Pasuruan', 26 October.

double function abandoned', 4 October.

2000 'Gus Dur; Sejak dulu sudah minta maaf', 15 March.

Kristof, Nicholas

1998 'Fears of sorcerers spur killings in Java', 20 October, www.geocities. com/CapitolHill/Senate/9389/safe_october98/fears_of_sorcerers_ Kroeger, Karen spur_killings.htm

2003 'AIDS rumors, imaginary enemies, and the body politic in Indonesia', LAKPESDAM-NU American Ethnologist 30:243-57.

1999 'Hasil penelitian tentang kasus pelanggaran HAM (pembunuhan terhadap "dukun santet" dan isu "ninja") yang terjadi di Jawa Timur, khususnya di Banyuwangi dan Jember'. [Manuscript.]

Langenberg, Michael van

1990 'Gestapu and state power in Indonesia', in: Robert Cribb (ed.), The Indonesian killings of 1965-1966; Studies from Java and Bali, pp. 45-61. Clayton VIC: Centre of Southeast Asian Studies, Monash University. [Monash Papers on Southeast Asia 21.]

Mansurnoor, Iik Arifin

$1990 \quad$ Islam in an Indonesian world; Ulama of Madura. Yogyakarta: Gadjah Mada University Press.

1992 'Local initiative and government plans; Ulama and rural development in Madura, Indonesia', Sojourn; Social Issues in South-East Asia 7:69-94. 
'Rato and kiai in Madura; are they twins?', in: Kees van Dijk, Huub de Jonge and Elly Touwen-Bouwsma (eds), Across Madura Strait; The dynamics of an insular society, pp. 25-48. Leiden: KITLV Press. [Proceedings 2.]

Margold, Jane

1999 'From "cultures of fear and terror" to the normalisation of violence; An ethnographic case', Cultural Anthropology 19:63-88.

Mietzner, Marcus 1999

'Nationalism and Islamic politics; Political Islam in the post-Suharto era', in: Arief Budiman, Barbara Hatley and Damien Kingsbury (eds), Reformasi; Crisis and change in Indonesia, pp. 173-200. Clayton VIC: Monash Asia Institute, Monash University. [Monash Papers on Southeast Asia 50.]

Moreau, Ron

1998 'Mystery of ninja assassins', Newsweek (23 November):15-17.

Nagengast, Carole

1994 'Violence, terror, and the crisis of the state', Annual Review of Anthropology 23:109-136.

Nitibaskara, Ronny

1993 'Observations on the practice of sorcery in Java', in: C.W. Watson and Roy Ellen (eds), Understanding witchcraft and sorcery in Southeast Asia, Noszlopy, Laura

pp. 123-34. Honolulu: University of Hawaii Press.

2003 'Ogoh-ogoh; The making of a "new tradition" in urban Bali'. Paper, 21st Conference of the Association of South-East Asian Studies of the United Kingdom.

Oposisi

1999 'Betulkah Soeharto dalang G30S / PKI?', 31/3-6/4.

Pemberton, John

$1994 \quad$ On the subject of 'Java'. Ithaca NY: Cornell University Press.

Perelli, Carla

1994

'Memoria de sangre; Fear, hope and dischantment in the Argentine', in: Jonathan Boyarin (ed.), Remapping memory; The politics of timespace, pp. 39-66. Minneapolis MN: University of Minnesota Press.

Priyono, Sumbogo, Khudori and Saifal Anam

1998 'Terror santet; ABRI sampai menteri kabinet kena tuduh', Gatra 50, 31

October, www.gatra.com/IV/50/LPTI-50.html

Purdey, Jemma

2004 'Describing kekerasan; Some observations on writing about violence in Indonesia after the New Order', Bijdragen tot de Taal-, Land- en Volkenkunde 160:189-225.

Retsikas, Konstantinos

2003 'People of mixed blood'; Ethnicity, personhood and sociality in East Java, Indonesia. PhD thesis, University of Edinburgh.

Riches, David

1986

'The phenomenon of violence', in: David Riches (ed.), The anthropology of violence, pp. 1-27. New York: Blackwell. 
Robinson, Geoffrey

1995 The dark side of paradise; Political violence in Bali. Ithaca NY: Cornell Uni-

Rosaldo, Renato versity Press. [Asia East by South.]

$1980 \quad$ Ilongot headhunting, 1883-1974; A study in society and history. Stanford CA: Stanford University Press.

Schulte Nordholt, Henk

2002 'A genealogy of violence', in: Freek Colombijn and J. Thomas Lindblad (eds), Roots of violence in Indonesia; Contemporary violence in historical SiaR News Service perspective, pp. 33-61. Singapore: ISEAS.

1998a 'Satuan ABRI diduga di belakang pembantaian Banyuwangi', 7 October.

1998b 'Dua angota Kopassus ditangkap di Banyuwangi', 20 October.

Siegel, James T.

1986 Solo in the New Order; Language and hierarchy in an Indonesian city. Princeton NJ: Princeton University Press.

1998 A new criminal type in Jakarta; Counter-revolution today. Durham NC: Duke University Press.

2001 'Suharto, witches', Indonesia 71:27-78.

Singapore Straits Times

1998a '2 killed in police raid on "hideouts"', 23 October.

1998b 'Mob lynches 4 "ninja” killers', 28 October, www.huaren.org/focus/ id/102898-01.html.

Skidmore, Monique

2003 'Darker than midnight; Fear, vulnerability, and terror in urban Burma (Myanmar)', American Ethnologist 30:5-21.

Slamet-Velsink, Ina

1994 'Traditional leadership in rural Java', in: Hans Antlöv and Sven Cederroth (eds), Leadership on Java; Gentle hints, authoritarian rule, pp. 33-56.

Richmond: Curzon. [Nordic Institute of Asian Studies, Studies in Asian Topics 16.]

Sluka, Jeffrey

2000 Death squad; The anthropology of state terror. Philadelphia: University of Pennsylvania Press.

Smith, Daniel Jordan

2001 'Ritual killing, 419, and fast wealth; Inequality and the popular imagination in southeastern Nigeria', American Ethnologist 28:803-26.

Spencer, Jonathan

1992 'Problems in the analysis of communal violence', Contributions to Indian Sociology 26(New Series):261-79.

Steedly, Mary Margaret

1999 'The state of culture theory in the anthropology of Southeast Asia', Annual Review of Anthropology 28:431-54.

Surya

1998 'Ribuan Banser siap hadang ninja', 28 October. 
Tapol

1998

'Java police round up madmen to safeguard them against mob lynchTaussig, Michael ing', 6 November, www.antenna.nl/indonesie/mn08137.html.

1984

'Culture of terror, space of death; Roger Casement and the explanation of torture', Comparative Studies in Society and History 26:467-97.

1987 Shamanism, colonialism and the wild man; A study in terror and healing. Chicago: Chicago University Press.

Telle, Kari

2000 'Feeding the dead; Reformulating Sasak mortuary practices', Bijdragen tot de Taal-, Land-en Volkenkunde 156:771-805.

Thufail, Fadjar 2005

'Ninjas in narratives of local and national violence in post-Suharto Indonesia', in: Mary S. Zurbuchen (ed.), Beginning to remember; The past in the Indonesian present, pp. 150-70. Singapore: Singapore University Press. [Critical Dialogues in Southeast Asian Studies.]

Tsing, Anna Lowenhaupt

1993 In the realm of the diamond queen; Marginality in an out-of-the-way place. Princeton NJ: Princeton University Press.

Tsintjilonis, Dimitri 2000

'A head for the dead; Sacred violence in Tana Toraja', Archipel 59:2750.

Watson, C.W. 1994

'Muslims and state in Indonesia', in: Hussin Mutalim and Taj ulIslam Hashmi (eds), Islam, Muslims and the modern state; Case-studies of Muslims in thirteen countries, pp. 174-96. New York: St. Martin's Press, Basingstoke: Macmillan.

Watson, C.W. and Roy Ellen (eds)

$1993 \quad$ Understanding witchcraft and sorcery in Southeast Asia. Honolulu: UniWessing, Robert versity of Hawaii Press.

1996 'Rumours of sorcery at an Indonesian university', Journal of Southeast Asia Studies 27:261-79.

Wikan, Unni

1987

'Public grace and private fears; Gaiety, offence and sorcery in North Bali', Ethos 15:337-65.

1990 Managing turbulent hearts; A Balinese formula for living. Chicago: University of Chicago Press.

Woodward, Mark R.

1989 Islam in Java; Normative piety and mysticism in the Sultanate of Yogyakarta. Tucson: University of Arizona Press. [Monographs of the Association Young, Kenneth for Asian Studies 45.]

1990 'Local and national influences in the violence of 1965', in: Robert Cribb (ed.), The Indonesian killings of 1965-1966; Studies from Java and Bali, pp. 63-99. Clayton VIC: Centre of Southeast Asian Studies, Monash University. [Monash Papers on Southeast Asia 21.] 
Zurbuchen, Mary S.

2002

'History, memory, and the "1965 incident" in Indonesia', Asian Survey 42:564-82.

2005

(ed.) Beginning to remember; The past in the Indonesian present. Singapore: Singapore University Press. [Critical Dialogues in Southeast Asian Studies.] 